\title{
ANALISIS FINANSIAL PETERNAKAN AYAM BURAS BERDASARKAN SKALA USAHA DI KABUPATEN JEMBER
}

\section{FINANCIAL ANALYSIS OF POULTRY BASED ON BUSINESS SCALE IN JEMBER DISTRICT}

Saptya Prawitasari ${ }^{1}$ ) dan Edhi Siswanto ${ }^{2}$ )

1) Program Studi Agribisnis, Fakultas Pertanian, UM Jember

2) Program Studi Ilmu Pemerintahan, Fakultas Ilmu Sosial dan Ilmu Politik UM Jember

E-mail: saptya_prawitasari@yahoo.co.id

\begin{abstract}
ABSTRAK
Penelitian ini berujuan untuk mengetahui kelayakan usaha, tingkat keuntungan usaha ternak ayam buras secara finansial ditinjau dari skala usaha. Penelitian berlokasi di Kecamatan Jombang, Kabupaten Jember. Data yang digunakan adalah data primer dan data sekunder, sedangkan alat analisisnya yaitu kuantitatif dan kualitatif. Hasil analisis disajikan dalam bentuk tabel dan diberikan penjelasan secara deskriptif. Berdasarkan hasil penelitian, dapat disimpulkan bahwa: (1) Usaha ternak ayam buras skala besar, skala menengah, dan skala kecil di Kecamatan Jombang, Kabupaten Jember layak untuk diusahakan ditinjau dari aspek finansial. Usaha ternak ayam buras skala besar menunjukkan nilai NPV yang positif Rp. 16.703.271; nilai Gross B/C lebih dari 1; nilai Net B/C lebih dari 1; nilai IRR lebih dari suku bungan yang berlakui dengan Payback Periode 10,3 bulan. Usaha ternak ayam buras skala menengah menunjukkan nilai NPV Positif Rp 3.019.804; Gross B/C lebih dari 1; Net B/C lebih dari 1; IRR lebih besar dari suku bunga yang berlaku dengan Payback Periode 7,7 bulan. Usaha ternak ayam buras skala kecil ditinjau dari aspek finansial layak untuk diusahakan, karena nilai NPV positif Rp 5.754.108; nilai Gross B/C lebih 1; nilai Net B/C lebih 1; nlai IRR lebih besar dari suku bunga berlaku dengan Payback Periode 9,5 bulan. (2) Ada perbedaan tingkat keuntungan dalam usaha ternak ayam buras berdasarkan skala usaha.
\end{abstract}

Kata kunci: Keuntungan, kelayakan usaha, ternak ayam

\begin{abstract}
The purpose of this study is to determine the feasibility and compare the level of profitability laying chicken livestock business in terms of business scale. Research is located in Jombang district, Jember city. The data used primary data and secondary data, while the analysis are quantitative and qualitative analysis. The results are presented in tables and descriptively given an explanation. Based on the research results, it can be concluded that: (1) laying chicken livestock businesses largescale, medium-scale and small-scale in Jombang district, Jember city worth the effort in terms of the financial aspects. Laying chicken livestock businesses large scale shows a positive $N P V$ value (= Rp. 16.703.271); Gross B/C $(=1,13)>1$; Net B/C $(=1,43)>1 ; \operatorname{IRR}(=6,63 \%)>i$ with PP 10,3 months. While businesses are laying chicken livestock medium scale shows positive NPV value $(=$ Rp. 3.019.804); Gross B/C $(=1,06)>1$; Net B/C $(=1,16)>1$; $\operatorname{IRR~}(=3,79 \%)>i$ with PP 7,7 months. Likewise, businesses are laying chicken livestock small scale in terms of financial aspect worth the effort, because the value of a positive NPV (=Rp. 5.754.108); Gross B/C $(=1,43)>1$; Net $B / C(=1,81)>1 ; \operatorname{IRR}(=8,37 \%)>i$ with PP 9,5 months. (2) There is a difference in the rate of profit in laying chicken livestock business based on the business scale.
\end{abstract}

Keyword: profit, feasibility, poultry

\section{PENDAHULUAN}

Usaha peternakan Ayam Buras semakin diminati sebagai alternatif sumber pendapatan bagi masyarakat di pedesaan maupun di sekitar perkotaan. Hal ini disebabkan oleh beberapa kondisi 
lingkungan strategis yg lebih memihak pada usaha peternakan Ayam Buras, antara lain adalah semakin terpuruknya usaha peternakan ayam ras skala kecil dan munculnya wabah penyakit flu burung yang sangat merugikan peternakan ayam ras mupun ayam kampung. Di samping itu, semakin terbukanya pasar produk Ayam Buras ikut mendorong berkembangnya peternakan Ayam Buras di Indonesia. Pasar telur Ayam Buras yang selama ini telah terbentuk masih sangat terbuka bagi peningkatan produksi karena permintaan yang ada pun belum bisa terpenuhi semuanya, sedangkan pasar daging Ayam Buras yang selama ini hanya dipenuhi secara terbatas oleh daging Ayam Buras peking yang diimpor secara perlahan mulai terbuka lebih luas.

Kajian yang mendalam mengenai usaha ternak Ayam Buras, terutama mengenai apakah usaha ternak ayam buras mampu memberikan benefit yang layak ditinjau dari aspek finansial bagi masyarakat (peternak) perlu dilakukan. Kelayakan usaha ternak ayam buras tercermin dari tingkat keuntungan yang diperoleh. Keuntungan diperoleh dari penerimaan dikurangi seluruh biaya produksi. Semakin tinggi penerimaan maka keuntungan yang diperoleh semakin besar dan sebaliknya. Sementara itu, penerimaan dipengaruhi oleh besarnya produksi dan harga. Semakin tinggi harga maka keuntungan semakin besar dan apabila harga rendah maka keuntungan semakin kecil. Selain itu, tingkat keuntungan yang diperoleh cenderung berbeda berdasarkan skala usahanya. Berdasarkan pola pemeliharaannya, skala usaha dibedakan menjadi skala kecil ( $<100$ ekor) dengan pola pemeliharaan intensif, skala menengah (100-500 ekor) dengan pola pemeliharaan intensif, dan skala luas (>500 ekor) dengan pola pemeliharaan intensif (Pustakadunia, 2014).

Selanjutnya, bagaimana kelayakan usaha ternak ayam buras jika terjadi perubahan harga jual dan jumlah output selama usaha peternakan tersebut berlangsung. Berdasarkan identifikasi masalah dan latar belakang yang telah diuraikan, maka perlu dicari solusinya untuk dapat memecahkan permasalahan apakah usaha ternak ayam buras di Kabupaten Jember mempunyai prospek yang baik dan layak bagi peternak Ayam Buras. Oleh karena itu, penelitian ini berujuan untuk mengetahui kelayakan usaha, tingkat keuntungan usaha ternak ayam buras secara finansial ditinjau dari skala usaha.

\section{METODOLOGI PENELITIAN}

Motede yang dipakai dalam penelitian ini adalah metode deskriptifkomparatif dan evaluatif. Penentuan 
lokasi penelitian ini menggunakan metode sampling disengaja (Purposive Method), sebagai daerah penelitian ditetapkan Kecamatan Jombang, Kabupaten Jember. Waktu penelitian usaha ternak ayam buras dilaksanakan pada tahun 2017. Jenis data yang digunakan terdiri dari data primer dan data sekunder. Obyek penelitian ini adalah peternak Ayam Buras di Kecamatan Jombang, Kabupaten Jember yang mengusahakan lahannya dengan usaha ternak ayam buras. Populasi petani usaha ternak ayam buras sebesar 128 orang. Sementara itu, responden yang dipilih ditentukan berdasarkan skala usaha ternak ayam buras, dengan ketentuan: (1) petani usaha ternak ayam buras skala besar dengan jumlah kepemilikan ayam buras lebih dari 500 ekor dengan pola pemeliharaan intensif, (2) skala menengah dengan jumlah kepemilikan antara 100500 ekor dengan pola pemeliharaan intensif, dan (3) skala kecil dengan jumlah kurang dari 100 ekor dengan pola pemeliharaan intensif. Selanjutnya masing-masing jenis skala usaha dipilih satu orang peternak ayam buras dengan menggunakan metode purposive sampling yaitu pengambilan sampel secara disengaja. Dengan demikian, jumlah responden dalam penelitian ini berjumlah tiga orang petani usaha ternak ayam buras.

\section{Metode Analisis Data}

Kelayakan usaha ternak ayam buras secara finansial dianalisis menggunakan beberapa indikator kriteria investasi yang meliputi: Net Present Value (NPV), Gross Benefit Cost Ratio (Gross B/C), Net Benefit Cost Ratio (Net B/C), Internal Rate of Return (IRR), dan Payback Period (PP). Selanjutnya tingkat keuntungan usaha ternak ayam buras skala besar, skala menengah, dan skala kecil dibandingkan dengan melihat nilai kriteria investasi NPV dan IRR pada discount factor tertentu.

\section{HASIL DAN PEMBAHASAN}

\section{Arus Biaya}

\section{Dana Investasi}

Kebutuhan dana investasi pada awal usaha ternak ayam buras diperoleh pemilik usaha skala besar, skala menengah, maupun skala kecil menggunakan dana yang bersumber dari modal sendiri. Kebutuhan dana investasi awal pada usaha ternak ayam buras skala besar, skala menengah, dan skala kecil ditampilkan pada Tabel 1 berikut. 
Tabel 1. Investasi Awal Usaha Ternak Ayam Buras Menurut Skala Usaha di Kecamatan Jombang, Kabupaten Jember, Tahun 2017

\begin{tabular}{lrrrrrr}
\hline \multirow{2}{*}{ Uraian } & \multicolumn{6}{c}{ Skala Usaha } \\
\cline { 2 - 7 } & \multicolumn{1}{c}{ Besar } & \multicolumn{1}{c}{ Menengah } & \multicolumn{2}{c}{ Kecil } \\
\cline { 2 - 7 } & $\mathbf{( R p )}$ & $\mathbf{( \% )}$ & \multicolumn{1}{c}{$(\mathbf{R p )}$} & \multicolumn{1}{c}{$(\boldsymbol{\%})$} & \multicolumn{1}{c}{$(\mathbf{R p )}$} & $(\boldsymbol{\%})$ \\
\hline Sewa lahan & 800.000 & 2,55 & 320.000 & 1,81 & 705.000 & 14,70 \\
Ayam Buras & 28.674 .000 & 92,79 & 15.340 .000 & 92,62 & 4.100 .000 & 73,07 \\
Peralatan & 1.776 .000 & 4,68 & 928.000 & 5,57 & 670.000 & 12,33 \\
\hline Total & $\mathbf{3 1 . 2 5 6 . 0 0 0}$ & $\mathbf{1 0 0 , 0 0}$ & $\mathbf{1 6 . 5 8 8 . 0 0 0}$ & $\mathbf{1 0 0 , 0 0}$ & $\mathbf{5 . 4 7 5 . 0 0 0}$ & $\mathbf{1 0 0 , 0 0}$ \\
\hline
\end{tabular}

Sumber: Hasil Analisis Data Primer (2017).

Berdasarkan Tabel 1 dapat dijelaskan bahwa, dana investasi total yang dibutuhkan pada tahun pertama usaha ternak ayam buras untuk skala besar dengan 717 Ayam Buras adalah Rp 31.256.000. Penggunaan dana investasi terbesar adalah pembelian Ayam Buras yang mencapai $91,76 \%$, sedangkan penggunaan dana terendah adalah sewa lahan yaitu $2,56 \%$. Pada usaha ternak ayam buras skala menengah dan kecil sebagian besar investasi adalah untuk pembelian Ayam Buras. Dari dana investasi total yang dibutuhkan pada awal usaha ternak ayam buras untuk skala menengah dengan 364 Ayam Buras adalah Rp 16.588.000, penggunaan terbesar adalah untuk pembelian Ayam Buras yang mencapai 92,60\%, sedangkan penggunaan dana terendah adalah sewa lahan yaitu $1,81 \%$. Sementara dana investasi total yang dibutuhkan pada awal usaha ternak ayam buras untuk skala kecil dengan 80 Ayam Buras adalah Rp 5.475.000. adapun penggunaan dana investasi terbesar adalah pembelian Ayam Buras dan sewa lahan yang masingmasing mencapai $73,06 \%$ dan $14,61 \%$ yang dibayarkan untuk sewa lahan selama 22 bulan, sedangkan dana terendah adalah pembelian peralatan yaitu $12,33 \%$.

Perbandingan biaya investasi antara usaha ternak ayam buras skala besar, skala menengah, dan skala kecil cukup mencolok, dikarenakan beberapa hal perbedaan meliputi: jumlah ayam buras yang diternakkan, dan luas lahan yang berkaitan langsung dengan pembelian peralatan untuk pembuatan kandang dan alat-alat lain. Jumlah Ayam Buras yang diternakkan oleh usaha ternak ayam buras skala besar adalah 717 ekor, di mana luas lahan yang digunakan adalah $54 \mathrm{~m}^{2}$. Lahan yang digunakan oleh usaha ternak ayam buras skala besar adalah lahan tegal. Lahan yang digunakan diasumsikan menyewa dengan harga sewa lahan Rp 200.000/ musim. Dengan demikian, apabila lahan digunakan selama 4 musim maka biaya sewa sebesar Rp 800.000 . 
Jumlah ayam buras yang diternakkan oleh peternak skala menengah adalah 364 ekor, di mana luas lahan yang digunakan adalah $30 \mathrm{~m}^{2}$. Lahan yang digunakan oleh usaha ternak ayam buras skala menengah adalah lahan pekarangan. Lahan yang digunakan diasumsikan menyewa dengan harga sewa lahan Rp 100.000/musim. Dengan demikian selama 3 musim maka biaya sewa sebesar Rp 300.000, sedangkan biaya pembelian peralatan adalah Rp 928.000.

Usaha ternak ayam buras skala kecil hanya memiliki populasi sebanyak 80 ekor. Lahan yang digunakan usaha ternak ayam buras skala kecil adalah 20 $\mathrm{m}^{2}$. Sebagaimana pada skala besar maupun skala menengah, lahan yang digunakan usaha ternak ayam buras skala kecil juga lahan pekarangan. Perhitungan harga sewa Rp 100.000/musim. Dengan demikian, selama 8 musim, maka besarnya biaya sewa lahan adalah $\mathrm{Rp}$ 800.000 dan biaya pembelian peralatannya adalah Rp 675.000. Dari rangkaian uraian di atas dapat disimpulkan bahwa, penggunaan dana investasi pada awal usaha ternak ayam buras yang dikeluarkan oleh pengusaha skala besar lebih besar dibandingkan skala menengah dan skala kecil.

\section{Biaya Proyek}

Suatu kegiatan atau proyek membutuhkan berbagai jenis biaya, yang disesuaikan dengan kondisi proyek. Biaya proyek adalah seluruh biaya yang dikeluarkan oleh suatu usaha untuk menghasilkan produk dan memasarkannya Puspita (2010) dalam Silvia (2014). Biaya proyek meliputi biaya investasi, biaya operasional, biaya pemeliharaan serta beberapa jenis biaya lain sesuai dengan kondisi proyek. Total biaya proyek usaha ternak ayam buras skala besar adalah Rp 131.740.000 dengan rata-rata biaya total per 100 Ayam Buras sebesar Rp 18.373.780. Penggunaan biaya terbesar adalah untuk biaya operasional dan pemeliharaan yang mencapai $76 \%$ dari total biaya proyek dengan rata-rata biaya operasional dan pemeliharaan per 100 Ayam Buras sebesar Rp 14.014.505. Sementara penggunaan biaya investasi mencapai $24 \%$ dari total biaya proyek dengan ratarata biaya investasi per 100 Ayam Buras sebesar Rp 4.359.275.

Sementara itu, total biaya proyek usaha ternak ayam buras skala menengah adalah $\mathrm{Rp}$ 53.704.000 dengan rata-rata biaya total per 100 Ayam Buras sebesar $\mathrm{Rp}$ 14.753.846. Penggunaan biaya terbesar adalah untuk biaya operasional dan pemeliharaan yang mencapai $69 \%$ dari total biaya proyek atau senilai 
$\mathrm{Rp}$ 37.116.000 dengan rata-rata biaya operasional dan pemeliharaan sebesar Rp 10.196.703. Penggunaan biaya lainnya adalah untuk biaya investasi yang mencapai $31 \%$ dari total biaya proyek atau senilai Rp 16.588.000 dengan rata-rata biaya investasi per 100 Ayam Buras sebesar Rp 4.557.143

Total biaya proyek usaha ternak ayam buras skala kecil adalah $\mathrm{Rp}$ 34.119.900 dengan rata-rata biaya total per 100 Ayam Buras sebesar Rp 42.649.875. Penggunaan biaya terbesar adalah untuk biaya operasional dan pemeliharaan yang mencapai $84 \%$ dari total biaya proyek atau senilai $\mathrm{Rp}$ 28.644.900 dengan rata-rata biaya pemeliharaan dan operasional per 100 Ayam Buras sebesar Rp 35.806.125. Penggunaan biaya terbesar berikutnya adalah untuk biaya investasi yang mencapai $16 \%$ atau senilai $\operatorname{Rp} 5.475 .000$ dengan rata-rata biaya investasi per 100 Ayam Buras sebesar Rp 6.843.750. Dari serangkaian uraian tersebut di atas menunjukkan bahwa besarnya biaya proyek usaha ternak ayam buras sangat ditentukan oleh besarnya skala usaha. Semakin besar skala usaha yang diusahakan, semakin besar biaya yang harus dikeluarkan, terutama biaya yang dikeluarkan untuk investasi awal dan operasional.

Tabel 2. Rata-rata Biaya Operasional dan Pemeliharaan per 100 Ayam Buras dan per Ekor Usaha Ternak Ayam Buras Menurut Skala Usaha

\begin{tabular}{|c|c|c|c|c|}
\hline & \multirow[b]{2}{*}{ Skala Usaha } & \multirow[b]{2}{*}{ Jumlah Ayam Buras } & \multicolumn{2}{|c|}{ Biaya $O \& P$} \\
\hline & & & $\begin{array}{l}\text { per } 100 \text { Ayam Buras } \\
\text { (Rp) }\end{array}$ & $\begin{array}{l}\text { per ekor } \\
(\mathbf{R p})\end{array}$ \\
\hline 1 & Besar & 717 & 14.024 .504 & 140.245 \\
\hline 2 & Menengah & 364 & 10.186 .702 & 101.867 \\
\hline 3 & Kecil & 80 & 35.806 .126 & 358.761 \\
\hline
\end{tabular}

Sumber: Hasil Analisis Data Primer (2017).

Tabel 2 ditunjukkan bahwa, ratarata biaya operasional dan pemeliharaan per 100 Ayam Buras yang dikeluarkan oleh usaha ternak skala besar untuk 717 ekor, yaitu Rp 14.014.504, sehingga biaya rata-rata per ekornya adalah $\mathrm{Rp} 140.142$. Berbeda dengan skala menengah, biaya operasional dan pemeliharaan rata-rata per 100 Ayam Buras yang dikeluarkan untuk
364 ekor adalah Rp 10.196.702, sehingga biaya rata-rata per ekornya yaitu $\mathrm{Rp}$ 101.867. Sementara untuk skala kecil dengan jumlah Ayam Buras 80 ekor, ratarata biaya operasional dan pemeliharaan per 100 Ayam Buras adalah Rp 35.806.126, dan biaya rata-rata per ekornya menjadi Rp 358.761. Fakta ini menunjukkan bahwa biaya rata-rata 
operasional dan pemeliharaan per ekor per

bulan yang dikeluarkan oleh usaha ternak ayam buras skala menengah lebih kecil dibandingkan skala besar dan skala kecil.

\section{Analisis Finansial}

\section{Arus Kas}

Analisis arus kas digunakan untuk menggambarkan bahwa kegiatan ekonomi dalam suatu usaha yang telah dilaksnakan. Arus kas menggambarkan nilai penerimaan dan total pengeluaran dalam suatu usaha. Arus kas masuk dalam usaha ternak ayam buras berasal dari penerimaan hasil penjualan telur Ayam Buras. Sementara arus kas keluar berasal dari biaya investasi, biaya operasional, dan biaya pemeliharaan.

Tabel 3. Arus Kas Usaha Ternak Ayam buras Skala Besar Periode Mei 2016-Maret 2017

\begin{tabular}{|c|c|c|c|c|c|c|}
\hline \multirow{2}{*}{ Bulan } & \multirow{2}{*}{ Bulan Ke } & \multicolumn{2}{|c|}{ Biaya (Rp) } & \multirow{2}{*}{$\begin{array}{c}\text { Total Biaya } \\
\text { (Rp) }\end{array}$} & \multirow{2}{*}{$\begin{array}{c}\text { Benefit } \\
\text { (Rp) }\end{array}$} & \multirow{2}{*}{$\begin{array}{c}\text { Net-Benefit } \\
\text { (Rp) }\end{array}$} \\
\hline & & Investasi & $O \& P$ & & & \\
\hline Mei & 1 & 30.656 .000 & 2.295 .000 & 32.951 .000 & - & $(32.951 .000)$ \\
\hline Juni & 2 & - & 8.844 .000 & 8.844 .000 & 2.305 .000 & $(6.539 .000)$ \\
\hline Juli & 3 & - & 10.241 .000 & 10.241 .000 & 13.130 .000 & 2.889 .000 \\
\hline Agustus & 4 & 200.000 & 10.657 .000 & 10.857 .000 & 16.920 .000 & 6.063 .000 \\
\hline September & 5 & - & 10.391 .000 & 10.391 .000 & 16.470 .000 & 6.079 .000 \\
\hline Oktober & 6 & - & 11.178 .000 & 11.178 .000 & 17.590 .000 & 6.412 .000 \\
\hline Nopember & 7 & 200.000 & 11.411 .000 & 11.611 .000 & 15.915 .000 & 4.304 .000 \\
\hline Desember & 8 & - & 12.876 .000 & 12.876 .000 & 14.575 .000 & 1.699 .000 \\
\hline Januari & 9 & - & 12.239 .000 & 12.239 .000 & 14.553 .500 & 2.314 .500 \\
\hline Pebruari & 10 & 200.000 & 6.281 .000 & 6.481 .000 & 7.466 .375 & 985.375 \\
\hline Maret & 11 & - & 4.071 .000 & 4.071 .000 & 34.000 .000 & 29.929 .000 \\
\hline Jumlah & & 31.256 .000 & 100.484 .000 & 131.740 .000 & 152.924 .875 & 21.184 .875 \\
\hline \multicolumn{2}{|c|}{ Rata-rata per 100 Ayam Buras } & 4.359.275 & 14.014.505 & 18.373.780 & 21.328.434 & 2.954 .655 \\
\hline \multicolumn{2}{|c|}{ Prosentase per bulan (\%) } & 24 & 76 & 100 & & \\
\hline
\end{tabular}

Sumber: Hasil Analisis Data Primer (2017).

Pada Tabel 3 menunjukkan bahwa net benefit usaha ternak ayam buras skala besar pada bulan ke-1 dan ke-2 masih negative. Hal ini karena usia ternak ayam buras masih 4,5 bulan dan belum berproduksi. Itulah sebabnya pada bulan ke-1 Ayam Buras masih belum bertelur, sehingga belum ada benefit yang diperoleh. Ayam Buras mulai belajar bertelur pada bulan ke-2, namun produksinya masih rendah.
Ayam Buras mulai bertelur pada bulan ke-3, sehingga mulai ada benefit dengan nilai net benefit sebesar $\mathrm{Rp}$ 2.889.000. Demikian hingga dengan bulan ke-6. Pada bulan ke-7 net benefit yang didapat mulai mengalami penurunan dikarenakan Ayam Buras memasuki masa rontok bulu sehinga terjadi penurunan hasil produksi. Rontok bulu merupakan proses alami yang tidak bisa dihindari dan merupakan fase istirahat produksi 
(Um_Mulyadi, 2014). Pada bulan ke-11 Ayam Buras sebanyak 700 ekor yang mengalami rontok bulu dijual sebagai ayam afkir sehingga menghasilkan nilai sisa. Oleh karena itu, net benefit yang diperoleh menjadi $\operatorname{Rp} 29.929 .000$.

Tabel 4. Arus Kas Usaha Ternak Ayam buras Skala Menengah 2017

\begin{tabular}{|c|c|c|c|c|c|c|}
\hline \multirow{2}{*}{ Bulan } & \multirow{2}{*}{ Bulan Ke } & \multicolumn{2}{|c|}{ Biaya (Rp) } & \multirow{2}{*}{$\begin{array}{c}\text { Total Biaya } \\
\text { (Rp) }\end{array}$} & \multirow{2}{*}{$\begin{array}{c}\text { Benefit } \\
\text { (Rp) }\end{array}$} & \multirow{2}{*}{$\begin{array}{l}\text { Net-Benefit } \\
\quad \text { (Rp) }\end{array}$} \\
\hline & & Investasi & $O \& P$ & & & \\
\hline April & 1 & 16.388 .000 & 2.376 .000 & 18.764 .000 & - & $(18.764 .000)$ \\
\hline Mei & 2 & - & 4.902 .000 & 4.902 .000 & 4.159 .175 & (742.825) \\
\hline Juni & 3 & - & 5.104 .000 & 5.104 .000 & 6.752 .000 & 1.648 .000 \\
\hline Juli & 4 & 100.000 & 5.522 .000 & 5.622 .000 & 9.045 .000 & 3.423 .000 \\
\hline Agustus & 5 & - & 5.522 .000 & 5.522 .000 & 8.816 .500 & 3.294 .500 \\
\hline September & 6 & - & 5.344 .000 & 5.344 .000 & 7.288 .125 & 1.944 .125 \\
\hline Oktober & 7 & 100.000 & 5.522 .000 & 5.622 .000 & 6.303 .250 & 681.250 \\
\hline Nopember & 8 & - & 2.824 .000 & 2.824 .000 & 15.660 .350 & 12.836 .350 \\
\hline Jumlah & & 16.588 .000 & 37.116 .000 & 53.704.000 & 58.024 .400 & 4.320 .400 \\
\hline \multicolumn{2}{|c|}{ Rata-rata per 100 Ayam Buras } & 4.557.143 & 10.196 .703 & 14.753 .846 & 15.940 .769 & 1.186 .923 \\
\hline \multicolumn{2}{|c|}{ Prosentase per bulan (\%) } & 31 & 69 & 100 & & \\
\hline
\end{tabular}

Sumber: Hasil Analisis Data Primer (2015).

Net benefit usaha ternak ayam buras skala menengah pada bulan ke-1 dan ke-2 negatif, yaitu sebesar Rp 18.764.000 dan $\operatorname{Rp} 742.825$. Hal ini disebabkan Ayam Buras yang diternakkan adalah Ayam Buras bayah umur 5 bulan dan belum memproduksi telur. Itulah sebabnya pada bulan ke-1 Ayam Buras masih belum bertelur, sehingga belum ada benefit yang diperoleh. Ayam Buras mulai belajar bertelur pada bulan ke-2, namun produksinya masih rendah. Pada bulan ke3 Ayam Buras sudah mulai bertelur, sehingga pada bulan tersebut mulai dihasilkan benefit dengan nilai net benefit sebesar Rp 1.648.000 dan terus meningkat sampai bulan ke-4. Pada bulan ke-5 net benefit yang didapat mulai mengalami penurunan dikarenakan kurangnya manajemen dan perawatan yang baik. Dengan manajemen dan perawatan yang baik, Ayam Buras akan berhenti bertelur setelah 12-14 bulan (Um_Mulyadi, 2014). Pada bulan ke-8 sebanyak 334 ekor Ayam Buras yang mengalami rontok bulu dijual sebagai afkiran sehingga menghasilkan nilai sisa dan net benefit menjadi $\mathrm{Rp}$ 13.170.350. 
Tabel 5. Arus Kas Usaha Ternak Ayam buras Skala Kecil

\begin{tabular}{|c|c|c|c|c|c|c|}
\hline \multirow[t]{2}{*}{ Bulan } & \multirow{2}{*}{ Bulan Ke } & \multicolumn{2}{|c|}{ Biaya (Rp) } & \multirow{2}{*}{$\begin{array}{c}\text { Total Biaya } \\
\text { (Rp) }\end{array}$} & \multirow{2}{*}{$\begin{array}{c}\text { Benefit } \\
\text { (Rp) }\end{array}$} & \multirow{2}{*}{$\begin{array}{c}\text { Net-Benefit } \\
\text { (Rp) }\end{array}$} \\
\hline & & Investasi & Operasional & & & \\
\hline Pebruari & 1 & $4,775,000$ & 541,200 & $5,316,200$ & - & $(5,316,200)$ \\
\hline Maret & 2 & - & $1,390,800$ & $1,390,800$ & 766,400 & $(624,400)$ \\
\hline April & 3 & - & $1,346,000$ & $1,346,000$ & $2,432,000$ & $1,086,000$ \\
\hline Mei & 4 & 100,000 & $1,390,800$ & $1,490,800$ & $2,465,825$ & 975,025 \\
\hline Juni & 5 & - & $1,346,000$ & $1,346,000$ & $1,995,200$ & 649,200 \\
\hline Juli & 6 & - & $1,372,200$ & $1,372,200$ & $1,834,450$ & 462,250 \\
\hline Agustus & 7 & 100,000 & $1,372,200$ & $1,472,200$ & $1,951,950$ & 479,750 \\
\hline September & 8 & - & $1,328,000$ & $1,328,000$ & $2,140,110$ & 812,110 \\
\hline Oktober & 9 & - & $1,348,950$ & $1,348,950$ & $2,433,750$ & $1,084,800$ \\
\hline Nopember & 10 & 100,000 & $1,305,500$ & $1,405,500$ & $2,266,650$ & 861,150 \\
\hline Desember & 11 & - & $1,348,950$ & $1,348,950$ & $1,528,350$ & 179,400 \\
\hline Januari & 12 & - & $1,348,950$ & $1,348,950$ & - & $(1,348,950)$ \\
\hline Pebruari & 13 & 100,000 & $1,238,600$ & $1,338,600$ & $1,782,400$ & 443,800 \\
\hline Maret & 14 & - & $1,348,950$ & $1,348,950$ & $2,796,225$ & $1,447,275$ \\
\hline April & 15 & - & $1,305,500$ & $1,305,500$ & $2,479,950$ & $1,174,450$ \\
\hline Mei & 16 & 100,000 & $1,348,950$ & $1,448,950$ & $2,218,050$ & 769,100 \\
\hline Juni & 17 & - & $1,305,500$ & $1,305,500$ & $1,705,000$ & 399,500 \\
\hline Juli & 18 & - & $1,348,950$ & $1,348,950$ & $1,890,000$ & 541,050 \\
\hline Agustus & 19 & 100,000 & $1,348,950$ & $1,448,950$ & $1,790,800$ & 341,850 \\
\hline September & 20 & - & $1,305,500$ & $1,305,500$ & $1,517,100$ & 211,600 \\
\hline Oktober & 21 & - & $1,348,950$ & $1,348,950$ & $1,452,550$ & 103,600 \\
\hline Nopember & 22 & 100,000 & $1,305,500$ & $1,405,500$ & $3,928,100$ & $2,522,600$ \\
\hline Jumlah & & $5,475,000$ & $28,644,900$ & $34,119,900$ & $41,374,860$ & $7,254,960$ \\
\hline Rata-rata p & Ayam Buras & $6,843,750$ & $35,806,125$ & $42,649,875$ & $\mathbf{5 1 , 7 1 8 , 5 7 5}$ & $9,068,700$ \\
\hline Prosentase & an $(\%)$ & $16 \%$ & $84 \%$ & $100 \%$ & & \\
\hline
\end{tabular}

Sumber: Hasil Analisis Data Primer (2017).

Net benefit usaha ternak ayam buras skala kecil pada bulan ke-1 dan ke2 negatif, yaitu sebesar Rp 5.316.200 dan Rp 624.400. Hal ini disebabkan Ayam Buras yang diternakkan adalah Ayam Buras bayah umur 5 bulan dan belum memproduksi telur. Itulah sebabnya pada bulan ke-1 Ayam Buras masih belum bertelur, sehingga belum ada benefit yang diperoleh (tabel 6.8). Ayam Buras mulai belajar bertelur pada bulan ke-2, namun produksinya masih rendah. Pada bulan ke3 Ayam Buras sudah mulai bertelur, sehingga pada bulan tersebut mulai dihasilkan benefit dengan nilai net benefit sebesar Rp 1.086.000.

Benefit yang dihasilkan pada bulan ke-4 sampai bulan ke-11 relatif fluktuatif. Pada bulan ke-12 Ayam Buras berhenti bertelur atau memasuki fase istirahat produksi. Um_Mulyadi (2014) mengungkapkan bahwa Ayam Buras akan istirahat produksi kira-kira 1,5-2 bulan sampai bertelur kembali. Net benefit pada bulan ke-12 negatif, yaitu sebesar Rp 1.348.950. Hal ini dikarenakan tidak ada benefit yang didapat, namun biaya operasional seperti pakan tetap 
berjalan.Pada bulan ke-13 Ayam Buras mulai bertelur kembali, sehingga pada bulan tersebut mulai dihasilkan benefit dengan nilai net benefit sebesar $\mathrm{Rp}$ 443.800 dan terus meningkat di bulan ke14. Pada bulan ke-15 sampai bulan ke-21 net benefit yang dihasilkan menunjukkan kecenderungan menurun yang disebabkan karena umur Ayam Buras yang semakin tua sehingga terjadi penurunan produksi.

\section{Kelayakan Investasi Usaha}

Tujuan mendirikan usaha adalah untuk mendapatkan keuntungan semaksimal mungkin untuk mempertahankan kelangsungan usaha. Suatu usaha dikatakan layak jika dapat memenuhi kriteria investasi dan memperoleh keuntungan sesuai yang diharapkan. Beberapa alat kriteria investasi yang digunakan untuk mengukur kelayakan suatu investasi ini antara lain: (1) NPV, (2) Gross BC, (3) Net B/C, (4) IRR, dan (5) Payback Period. Suatu proyek dapat dikatakan layak jika nilai NPV yang dihasilkan menunjukkan angka positif, nilai Gross B/C dan Net BC lebih dari 1, tingkat IRR yang diperoleh lebih besar dari tingkat suku bunga yang berlaku dan masa kembali modal tidak dalam waktuu yang lama.

Discount factor yang digunakan adalah tingkat suku bunga bank yang berlaku pada saat mulai berdirinya usaha.
Discount factor yang digunakan untuk usaha ternak ayam buras adalah 12,18\% per tahun atau $1,015 \%$ per bulan sesuai dengan tingkat suku bunga bank BRI di Kecamatan Jombang yang berlaku pada tahun 2016. Perhitungan data dari usaha ternak ayam buras skala besar, dilakukan pada periode waktu usaha bulan Mei 2016-Maret 2017 untuk mengetahui kelayakan usaha dan tingkat keuntungan.

Nilai NPV usaha ternak ayam buras pada discount factor $12,18 \%$ per tahun atau 1,015\% per bulan sebesar Rp 16.776.077 atau lebih besar dari nol. Artinya, bahwa usaha tersebut secara finansial layak untuk dilanjutkan. Nilai Gross $\mathrm{B} / \mathrm{C}$ dari usaha ternak ayam buras skala besar adalah 1,13 atau lebih besar dari satu. Artinya, setiap rupiah nilai biaya total sekarang yang dikeluarkan akan menghasilkan sebesar $\mathrm{Rp} \quad 1,13$ nilai benefit sekarang. Hal ini menunjukkan bahwa usaha tersebut secara finansial layak untuk dilanjutkan. Nilai Net B/C dari usaha ternak ayam buras skala besar adalah 1,43 atau lebih besar dari satu, yang artinya setiap rupiah biaya total yang dikeluarkan akan menghasilkan NPV positif lebih sebesar daripada NPV negative. Dengan demikian, berdasarkan perhitungan Net B/C usaha ternak ayam buras skala besar secara finansial layak untuk dilanjutkan. 
Tabel 6. Hasil Analisis Finansial Usaha Ternak Ayam buras Skala Besar di Kecamatan Jombang, Kabupaten Jember, Tahun 2017

\begin{tabular}{llccc}
\hline \multicolumn{1}{c}{ Kriteria Investasi } & Nilai & Hasil & Keputusan \\
\hline 1 & NPV $(1,015 \%)$ & Rp 16.776 .077 & $>0$ & Layak dilanjutkan \\
2 & Gross B/C & 1,13 & $>1$ & Layak dilanjutkan \\
3 & Net B/C & 1,43 & $>1$ & Layak dilanjutkan \\
4 & IRR & $6,43 \%$ & $>\mathrm{i}$ & Layak dilanjutkan \\
5 & Payback Period & 10,3 bulan & & Layak dilanjutkan \\
\hline
\end{tabular}

Sumber: Hasil Analisis Data Primer (2017).

Nilai IRR dari usaha ternak ayam buras skala besar adalah 6,63\%. Artinya, pada saat NPV $=$ Rp 0 diperoleh tingkat keuntungan sebesar $6,63 \%$ per bulan atau tingkat keuntungan yang diperoleh lebih tinggi dari tingkat suku bunga yang berlaku $(1,015 \%$ per bulan). Hal ini menunjukkan bahwa usaha ternak ayam buras skala besar secara finansial layak untuk dilanjutkan. Nilai payback period dari usaha ternak ayam buras skala besar adalah 10,3 bulan. Artinya, bahwa investasi yang ditanamkan pada awal pendirian usaha dapat kembali ketika
Ayam Buras dijual sebagai nilai sisa dalam periode usaha dalam jangka waktu relatif cepat, yaitu 10,3 bulan. Berdasarkan uraian tersebut dapat disimpulkan bahwa usaha ternak ayam buras skala besar secara finansial layak untuk dilanjutkan. Hasil analisis data dari usaha ternak ayam buras skala menengah menggunakan discount factor sesuai dengan tinggkat suku kredit bank setempat yang berlaku pada tahun 2014 adalah $12,18 \%$ per tahun atau $1,015 \%$ per bulan.

Tabel 7. Hasil Analisis Finansial Usaha Ternak Ayam buras Skala Menengah di Kecamatan Jombang, Kabupaten Jember, Tahun 2017

\begin{tabular}{|c|c|c|c|}
\hline Kriteria Investasi & Nilai & Hasil & Keputusan \\
\hline $1 \quad \operatorname{NPV}(1,015 \%)$ & Rp 3.019.804 & $>0$ & Layak dilanjutkan \\
\hline 2 Gross B/C & 1,06 & $>1$ & Layak dilanjutkan \\
\hline 3 Net B/C & 1,16 & $>1$ & Layak dilanjutkan \\
\hline 4 IRR & $3,79 \%$ & $>\mathrm{i}$ & Layak dilanjutkan \\
\hline 5 Payback Period & 7,7 bulan & & Layak dilanjutkan \\
\hline
\end{tabular}

Sumber: Hasil Analisis Data Primer (2017)

Nilai NPV usaha ternak ayam buras skala menengah menggunakan discount factor $1,015 \%$ per bulan sebesar Rp 3.019.804 atau lebih besar dari nol. Hal ini menunjukkan bahwa usaha ternak ayam buras skala menengah secara finansial layak untuk dilanjutkan. Sementara nilai Gross B/C dari usaha 
ternak ayam buras skala menengah adalah 1,06 atau lebih besar dari satu. Artinya, setiap rupiah nilai biaya total sekarang yang dikeluarkan akan memberikan sebesar $\mathrm{Rp}$ 1,06 nilai benefit sekarang. Hal ini menunjukkan bahwa usaha tersebut secara finansial layak untuk dilanjutkan karena NPV benefit lebih besar dari NPV biaya.

Net $B / C$ dari usaha ternak ayam buras skala menengah adalah 1,16 atau lebih besar dari satu. Artinya, setiap rupiah biaya total yang dikeluarkan akan menghasilkan NPV positif lebih sebesar daripada NPV negatif. Dengan demikian, berdasarkan analisis Net B/C menunjukkan bahwa usaha ternak ayam buras skala menengah secara finansial layak untuk dilanjutkan. Nilai IRR dari usaha ternak ayam buras skala menengah adalah 3,79\%. Artinya, pada saat NPV = Rp 0 akan diperoleh tingkat keuntungan sebesar $3,79 \%$ per bulan atau tingkat keuntungan yang diperoleh lebih tinggi dari tingkat suku bunga yang berlaku (1,015\% per bulan). Hal ini menunjukkan bahwa usaha ternak ayam buras skala menengah secara finansial layak untuk dilanjutkan.

Nilai payback period dari usaha ternak ayam buras skala menengah adalah 7,7 bulan. Artinya, bahwa investasi yang ditanamkan pada awal pendirian usaha dapat kembali ketika Ayam Buras dijual sebagai nilai sisa dalam periode usaha dalam jangka waktu yang relatif cepat, yaitu 7,7 bulan. Berdasarkan uraian tersebut dapat disimpulkan bahwa usaha ternak ayam buras skala besar secara finansial layak untuk dilanjutkan. Analisis data dari usaha ternak ayam buras skala kecil di Kecamatan Jombang menggunakan discount factor sesuai dengan tinggkat suku kredit bank setempat yang berlaku pada tahun 2016, yaitu $12,18 \%$ per tahun atau $1,015 \%$ per bulan.

Tabel 8. Hasil Analisis Finansial Usaha Ternak Ayam buras Skala Kecil di Kecamatan Jombang, Kabupaten Jember, Tahun 2017

\begin{tabular}{llccc}
\hline & \multicolumn{1}{c}{ Kriteria Investasi } & Nilai & Hasil & Keputusan \\
\hline 1 & NPV $(1,015 \%)$ & Rp 5.754 .108 & $>0$ & Layak dilanjutkan \\
2 & Gross B/C & 1,19 & $>1$ & Layak dilanjutkan \\
3 & Net B/C & 1,81 & $>1$ & Layak dilanjutkan \\
4 & IRR & $8,37 \%$ & $>\mathrm{i}$ & Layak dilanjutkan \\
5 & Payback Period & 9,5 bulan & & Layak dilanjutkan \\
\hline
\end{tabular}

Sumber: Hasil Analisis Data Primer (2017). 
Tabel 8 menunjukkkan nilai NPV usaha ternak ayam buras skala kecil pada discount factor $1,015 \%$ per bulan sebesar Rp 5.754.108 atau lebih besar dari nol. Hal ini menunjukkan bahwa kegiatan usaha ternak ayam buras skala kecil secara finansial selama periode tersebut layak untuk dilanjutkan. Demikian pula halnya untuk indikator kriteria investasi lainnya. Nilai Gross B/C dari usaha ternak ayam buras skala kecil adalah 1,19 atau lebih besar dari satu, yang artinya bahwa usaha tersebut secara finansial layak untuk dilanjutka. Nilai Net B/C dari usaha ternak ayam buras skala kecil lebih dari satu, yaitu 1,81. Artinya, setiap rupiah biaya total yang dikeluarkan hanya akan dihasilkan NPV positif lebih sebesar daripada NPV negatif. Maka usaha ternak ayam buras skala kecil secara finansial layak untuk dilanjutkan.

Nilai IRR dari usaha ternak ayam buras skala kecil adalah 8,37\%. Artinya, pada saat NPV $=$ Rp 0 akan diperoleh tingkat keuntungan sebesar $8,37 \%$ per bulan atau tingkat keuntungan yang diperoleh lebih tinggi dari tingkat suku bunga yang berlaku (1,015\% per bulan). Hal ini menunjukkan bahwa usaha ternak ayam buras skala kecil secara finansial layak untuk dilanjutkan. Nilai payback period dari usaha ternak ayam buras skala kecil adalah 9,5 bulan. Artinya, investasi yang ditanamkan pada awal pendirian usaha dapat kembali dalam jangka waktu relatif cepat, yaitu 9,5 bulan. Hal ini menunjukkan bahwa usaha ternak ayam buras skala kecil layak untuk dilanjutkan. Dapat disimpulkan bahwa usaha ternak ayam buras skala besar, skala menengah, dan skala kecil secara finansial layak untuk diusahakan, karena mampu memberikan benefit yang menguntungkan secara finansial.

\section{Masa Pengembalian Investasi}

Analisis payback period digunakan untuk mengetahui berapa lama usaha yang dilakukan dapat mengembalikan dana yang telah diinvestasikan. Semakin cepat dalam pengembalian biaya investasi sebuah usaha atau proyek, maka semakin baik proyek tersebut untuk dilaksanakan. Hasil analisis payback period dari usaha ternak ayam buras skala besar adalah 10,3 bulan. Artinya, bahwa investasi yang ditanamkan pada awal pendirian usaha dapat kembali ketika Ayam Buras dijual sebagai nilai sisa dalam jangka waktu yang relatif cepat, yaitu 10,3 bulan.

Hasil analisis payback period usaha ternak ayam buras skala menengah adalah 7,7 bulan. Artinya, bahwa investasi yang ditanamkan pada awal pendirian usaha dapat kembali ketika Ayam Buras dijual sebagai nilai sisa dalam jangka waktu yang relatif cepat, yaitu 7,7 bulan. Analisis payback period dari usaha ternak 
ayam buras skala kecil periode adalah 9,5 bulan. Hal tersebut menunjukkan bahwa usaha ini mampu mengembalikan investasi yang dikeluarkan melalui keuntungan yang diperoleh dalam jangka waktu relatif cepat, yaitu 9,5 bulan. Berdasarkan uraian di atas menunjukkan bahwa, usaha ternak ayam buras mampu mengembalikan modal yang telah diinvestasikan dalam waktu yang relatif cepat, yaitu skala menengah karena dilaksanakan dengan periode waktu usaha yang lebih cepat daripada skala usaha besar dan skala kecil.

\section{KESIMPULAN}

Berdasarkan perumusan masalah, tujuan penelitian, hipotesis, serta hasil penelitian dan pembahasan, maka dapat disimpulkan bahwa usaha ternak ayam buras skala besar, skala menengah, dan skala kecil di Kecamatan Jombang, Kabupaten Jember layak untuk diusahakan ditinjau dari aspek finansial. Usaha ternak ayam buras skala besar menunjukkan nilai NPV yang positif ( $=\mathrm{Rp}$ 16.703.271); Gross B/C > $1(=1,13)$; Net $\mathrm{B} / \mathrm{C}>1(=1,43) ; \mathrm{IRR}>\mathrm{i}(=6,63 \%)$ dengan PP 10,3 bulan. Sementara usaha ternak ayam buras skala menengah menunjukkan nilai NPV Positif (=Rp 3.019.804); Gross $\mathrm{B} / \mathrm{C}>1(=1,06) ; \mathrm{Net} \mathrm{B} / \mathrm{C}>1(=1,16) ;$ IRR $>$ i $(=3,79 \%)$ dengan PP 7,7 bulan.
Demikian juga usaha ternak ayam buras skala kecil ditinjau dari aspek finansial layak untuk diusahakan, karena nilai NPV positif (=Rp 5.754.108); Gross B/C > 1 $(=1,43) ;$ Net $\mathrm{B} / \mathrm{C}>1(=1,81) ; \mathrm{IRR}>\mathrm{i}$ $(=8,37 \%)$ dengan PP 9,5 bulan.

\section{DAFTAR PUSTAKA}

BPS Kabupaten Jember. 2014. Kecamatan Jombang Dalam Angka Tahun 2014. Kabupaten Jember: Badan Pusat Statistk Kabupaten Jember.

Kadariah. 1988. Evaluasi Proyek Analisa Ekonomis. $\quad$ Edisi $\mathrm{Ke}-2$. Universitas Indonesia: Lembaga Penerbit Fakultas Ekonomi.

Pustakadunia. 2014. Analisa Financial Usaha Budidaya Ayam Buras / Bebek Dan Produk Turunannya. http://www.pustakadunia.com/arti kel-pustaka-umum/analisafinancial-usaha-budidaya-Ayam Buras-bebek/. Diakses tanggal 4 Juni 2014.

Silvia. 2014. Analisis Kelayakan dan Sensitivitas Agribisnis Buah Naga. Skripsi (tidak dipublikasikan). Jember: Universitas Muhammadiyah. 